\title{
CHANGES IN THE FAMILY IN MACEDONIA
}

\begin{abstract}
The subject of this text is the analysis of changes in the size, composition and basic features of households and families. The importance of this analysis is seen in the fact that the family is a special institution within which the biological and the socioeconomic reproduction of the population takes place. The analysis presented in this text is descriptive, based on data from the Census of Population, Households and Dwellings, conducted in 1994 and 2002, as well as census data in other census years and data from vital statistics.
\end{abstract}

Keywords: HOUSEHOLD, FAMILY, CENSUS, MACEDONIAN CONTEXT

\section{Introduction}

Basically, social institutions, if they change, do so very slowly. Based on the existing analysis, marriage and family deviate from this trend of slow change. Data shows that in more than five decades, the structure of these institutions has changed rapidly. There are changes in the form of the family, the relationship between the partners, as well as the birth of children. The reasons are numerous, but the consequences are also seen on different levels and have a certain delayed effect.

In the European context, the period of the fifties and sixties of the $\mathrm{XX}$ century is known as the baby boom, a period when high fertility rates are recorded. During that time, most of the children's education, health, and well-being expenses were covered by the states and less by the families. In addition, it is a period after the end of World War II and a time of extremely high economic development. Monthly incomes and salaries were high, employment as well, and housing costs were not a problem. In general, this period is marked as a time when the realization of the role of a parent could be achieved without more serious difficulties.

However, after such a period of prosperity, the number of births of children begins to decline and this declining trend persists until the eighties and nineties of the XX century, when already due to the reduced number of births, the population is brought below the level of replacement. In general, the explanations are due to the fact that both the male and female population aspires to acquire higher education from the primary level, and the participation of 
women in the labour force increases. Consequently, this constellation strengthens the status and role of women in society. In addition, the late $\mathrm{XX}$ and early XXI centuries are characterized as a period in which it is more difficult to find a job, it is much more difficult for individuals to have their own home, and housing costs are rising. Undoubtedly, such a social context, which includes changes in the demographic behaviour of the population, also results in changes in the model of family formation and the birth of children. Add to that the fact that modern contraceptives are readily available, abortion is safer and freer, and future parents have room for individual choice in the realm of their own demographic behaviour.

In this context, the survival of the family in its previous forms and structures is unrealistic. The modern family is complicated, both in terms of its functioning and in terms of its position in society.

Mentioned the following time periods and using the statistical data, this paper focuses on the families in the Macedonian context, which basically does not deviate from the European trend of demographic development.

The subject of this text is the analysis of changes in the size, composition and basic features of households and families. The importance of this analysis is seen in the fact that the family is a separate institution within which the biological and the socioeconomic reproduction of the population takes place.

The analysis presented in this text is descriptive and based on data from the Censuses for the population, households and dwellings conducted in 1994 and 2002, at that time the Republic of Macedonia, ${ }^{1}$ as well as census data of other census years and data from vital statistics.

\section{Basic characteristics of the households and families}

Households are the basis for statistical analysis of families, and in that respect this analysis begins with the basic data about them. According to the methodology of the State Statistical Office (SSO), a household is represented by "a family or other unity of persons who have declared that they live together, and jointly spend the budget to meet their household needs, food and other necessities, regardless of whether all members are permanently located in the place where they reside or some of them reside elsewhere in or outside the country" (SSO, 2005: 10). By this definition, a household is a broader form of family. In particular, the household includes people who live together who have not formed a family, such as persons living alone or persons living with multiple members and who have not established family relations.

According to the SSO methodology, the family, as the basic unit of analysis, is a community of a married man and woman or partners who live to-

${ }^{1}$ The Republic of North Macedonia has not realized this regular statistical activity since 2002, which has not observed the usual ten-year period for the realization of the census. This fact constitutes an objective limitation on the subject matter of this paper. 
gether with their born or adopted children, but who are not married or married (SSO, 2005: 10). Basically, this determination is in accordance with the definition of the family in the Family Law contained in Article 2: "the family is the parents and children and other relatives, who live in a common household. The family is formed by the birth of children and by adoption". ${ }^{2}$

Data shows that in the past century, the number of households in Macedonia has increased, but the number of household members has decreased. Compared to the data from the last Census of Population, Households and Dwellings (2002), the number of households increased by approximately three times compared to the census data from 1921, when there were 146,141 households. In contrary, the average number of household members decreased by almost two members, from 5.53 in 1921 to 3.58 in 2002. In 2002, there were 564, 237 households in the Macedonia, ${ }^{3}$ which is $12.4 \%$ more than in 1994.

In 2002, at the state level, the average number of household members decreased from 3.9 to 3.6. As could be noticed, families are still a dominant community that gather the individuals. Namely, in 2002, the share of the population living in family households 4 in the total population is $93.5 \%$. In the category of non-family households, $2.7 \%$ of the total population lives in single-family households, and $3.8 \%$ in multi-member households. Compared to the European experience, these numbers are lower.

The data show that family households are predominant over non-family households. Specifically, in the total number of individual households, family households participate with $89.6 \%$ (78.4 with one household and $11.2 \%$ with more households), and non-households with $10.4 \%$ (with one member $9.5 \%$ and $0.9 \%$ with more members).

The data on the structure of households support the same conclusion, but also add that the form of coexistence of several generations under one roof or the so-called extended family is gradually being lost. In the period between the two censuses, the share of single-family families, such as nuclear families, increased by $16.3 \%$ in 2002 , and the number of large families or extended families decreased by $17.18 \%$. Specifically, in 1994, out of the total number of families, $70.46 \%$ were nuclear and $29.54 \%$ were extended families. Whereas, in 2002, the share of nuclear families increased to $77.01 \%$, and the share of enlarged ones decreased to $22.99 \%$ (see Table 1 ).

\footnotetext{
${ }^{2}$ Family Law (consolidated text) Official Gazette of RM, No. 153 of 20.10.2014.

${ }^{3}$ SSO, Census of Population, Households and Dwellings and Agricultural Holdings in the Republic of Macedonia, Book XIII Table 7, p. 46

${ }^{4}$ Households are divided into collective and individual. Individual households are divided into family (in which people with one or more families live) and non-family (in which individuals or persons living together, but not a family live). SSO, Census of Population, Households and Dwellings and Agricultural Holdings in the Republic of Macedonia, Book XIII, pp.10-11.
} 
Table 1. Number and Percentage Structure of Households by Number of Families, Republic of Macedonia, 1994 and 2002

\begin{tabular}{|c|c|c|c|c|c|}
\hline \multirow{2}{*}{ Year } & \multicolumn{2}{|c|}{ Families } & \multicolumn{2}{c|}{$\begin{array}{c}\text { Participation in the total } \\
\text { number of families (in \%) }\end{array}$} \\
\cline { 2 - 6 } & Total & One family & $\begin{array}{c}\text { Two and more } \\
\text { families }\end{array}$ & One family & $\begin{array}{c}\text { Two and more } \\
\text { families }\end{array}$ \\
\hline 1994 & 539.555 & 380.171 & 159.384 & 70,5 & 29,5 \\
\hline 2002 & 574.159 & 442.159 & 13.200 & 77,0 & 22,3 \\
\hline
\end{tabular}

Source: for 1994: Statistical Office, Census of Population, Households and Dwellings and Agricultural Holdings in the Republic of Macedonia, Book VIII, Table 14, p.42. for 2002: SSO, Census of Population, Households and Dwellings and Agricultural Economies in the Republic of Macedonia, 2002, Book II, Table 10, p. 102-103.

The changes in the family in terms of the number, and size as well are seen as a consequence of the stratification of large households into small family households. Such a process takes place under the influence of economic development, the reduction of the number of children in the family, i.e. the changes in reproductive behaviour, but also the intensive process of demographic aging, the change in marriage, and the increase in divorces.

\section{Family type}

The next criterion for determining the type of family is the form of union between the man and the woman. Could be within the marriage ${ }^{5}$ or in cohabitation union. ${ }^{6}$

Data shows that the marriage is the predominant form on which a family is shaped. The share of families in which the partners live together, but have not married, in the total number of families is $1.5 \%(0.7 \%$ are childless and $0.8 \%$ with children). Compared to the European experience, this form of family communities is lower, but the possibility that in the future de-institutionalization of partners' behaviour in relation to their relations will not develop with stronger dynamics should not be left out. According to the census data, in the

5 "Marriage is a law that regulates the life of a man and a woman in which the interests of the spouses, the family and the society are realized." Law on Family, Official Gazette of RM, No. 153 of 20.10.2014, Article 6. In the same Article it is emphasized that the conclusion of a marriage is based on free will, a joint decision. The minimum age for marriage is 18 , and people between the ages of 16 and 17 can get married, but under special legal provisions.

6 "Cohabitation between man and woman which is not based on the provisions of this Law (extramarital union) and which lasted for at least one year, is equated with the marital union in terms of the right to mutual support and property acquired during the duration of that community. ("Family Law" Official Gazette of the Republic of Macedonia, No. 153 of 20.10.2014, Art. 13). 
total number of families the category of families with children is decreasing. If in 1971 there were $74.4 \%$ of families with children, in 1994 it was $65.9 \%$ and slightly lower $(64.5 \%)$ in 2002 . However, if we add the category "community with children" to the previous category, we can say that the share of families with children is $65.3 \%$ and it can be concluded that there is no change between 1994 and 2002. In contrary to this tendency, families without children show an increase from $17.6 \%$ in 1971 to $25.3 \%$ in 2002 , due to a decrease in the number of births (see Table 2).

Table 2. Families by marriage and parenthood, RM, 1971, 1981, 199 and 2002

\begin{tabular}{|c|c|c|c|c|}
\hline \multirow{2}{*}{ Family type } & \multicolumn{4}{|c|}{ Year } \\
\hline & $\begin{array}{l}1971 \text { in \% } \\
\text { (n) }\end{array}$ & $\begin{array}{l}1981 \text { in \% } \\
\text { (n) }\end{array}$ & $\begin{array}{l}1994 \text { in \% } \\
\text { (n) }\end{array}$ & $\begin{array}{l}2002 \text { in \% } \\
\text { (n) }\end{array}$ \\
\hline $\begin{array}{l}\text { A married couple without } \\
\text { children }\end{array}$ & 17,6 & $\begin{array}{c}20,3 \\
(100.624)\end{array}$ & $\begin{array}{c}24,5 \\
(132.088)\end{array}$ & $\begin{array}{c}25,3 \\
(145.376)\end{array}$ \\
\hline $\begin{array}{l}\text { A married couple with } \\
\text { children }\end{array}$ & 74,4 & $\begin{array}{c}73,6 \\
(365.641)\end{array}$ & $\begin{array}{c}65,9 \\
(355.825)\end{array}$ & $\begin{array}{c}64,5 \\
(370.439)\end{array}$ \\
\hline $\begin{array}{l}\text { Cohabitation union without } \\
\text { children }\end{array}$ & & & & $0,7(3.966)$ \\
\hline $\begin{array}{l}\text { Cohabitation union with } \\
\text { children }\end{array}$ & & & & $0,8(4.573)$ \\
\hline Mother with children & 5,9 & $5,0(24.669)$ & $7,7(41.435)$ & $6,9(39.523)$ \\
\hline Father with children & 2,1 & $1,1(5.608)$ & $1,9(10.207)$ & $1,8(10.282)$ \\
\hline
\end{tabular}

Source: for 1981, Childbirth in SFR Yugoslavia. State Statistical Office; Table 5 for 1994 and 2002 same as Table 1.

Families of only one parent have uneven dynamics. Overall, there were 8.1 $\%$ in $1971,6.1 \%$ in $1981,9.6 \%$ in 1994, and a decline of $8.7 \%$ in 2002 for singleparent families with children (see Table 2). What is clear is that, within all observed periods, the participation of fathers with children in comparison to mothers with children is lower. One explanation for the different dynamics, at least between 1994 and 2002, is that since 2002, couples living in the cohabitation union have been seen as a separate type of family.

Regardless of the fact that the participation of couples who live in cohabitation union and families with one parent is not represented on a large scale compared to the European experience. Moreover, the trend of the cohabitation union should be monitored in the forthcoming period. It is necessary to explore 
their differentiation, the motives for the formation of this type of union and what is especially important is the way of functioning and lifestyles.

The general perception is that the number of families is increasing, but the size of families is decreasing, and thus the composition of families is changing. And, without deeper analysis, the main reason for this decrease in the number of families is due to the decrease in the number of births of children. Given that the majority of live births are still in a marriage, the decrease in the number of births, and thus the size of the family, is due to the delay in the birth of children 7 and marriage. ${ }^{8}$

\section{Families with children}

Data shows that one third of the total number of families with children is with one child.

Table 3: Number and Percentage of Families, by number of children, 1994 \& 2002

\begin{tabular}{|c|c|c|c|c|}
\hline \multirow{2}{*}{ Number of children } & \multicolumn{4}{|c|}{ Year } \\
\cline { 2 - 5 } & \multicolumn{2}{|c|}{1994} & Number & $\%$ \\
\cline { 2 - 5 } & Number & $\%$ & 424.817 & 100,0 \\
\hline Total & 407.467 & 100,0 & 153.054 & 36,0 \\
\hline One & 138.059 & 33,9 & 204.459 & 48,1 \\
\hline Two & 196.770 & 48,3 & 47.871 & 11,3 \\
\hline Three & 47.988 & 11,8 & 13.554 & 3,2 \\
\hline Four & 15.389 & 3,8 & 5.879 & 1,4 \\
\hline Five+ & 9.261 & 2,3 & & \\
\hline
\end{tabular}

Source: Same as Table 2.

The analysis of the changes between the two census periods does not show major changes, but there is a tendency of reduced participation of each category separately. From this trend, the category of single-parent families increased by about four percent in 2002 compared to 1994 (from 33.9\% to 36.0\%). The decrease in birth rates is also confirmed in terms of the structure of families with children under 15 years of age. Comparison of data between the two censuses shows that the number of this category of families decreased from 59.3\% in 1994 to $53.8 \%$ (52.9\% of married couples with and $0.9 \%$ without children) in 2002 .

${ }^{7}$ In 1994, the average age of the mother at birth was 23.5, in 2008 it was 25.6, and in 2001 it was 26. Regarding the total number of births, the average age of the mother increases from 26.8 in 1994 to 27.4 in 2008, SSH, Statistical Yearbook p. 83.

${ }^{8}$ During the observed period, in 1994, 8.1 marriages per 1000 inhabitants were registerred, in 20046.9 marriages per 1,000 inhabitants were registered and this number increased to 7.6 in 2007, to show a trend of reduced values in in the following years, in 2010, 6.9 and 7.2 marriages per 1000 inhabitants were registered. 


\section{Single person household}

According to the definition of family, single households are not families. However, the trend of increasing the share of this type of households and in the context of current demographic trends, we will continue to focus on this form of life organization. In rich countries, this type of family is becoming more common, especially among young people. This is due to the relative abundance in which families live and which allows young people the right to choose a residence. What is the Macedonian experience like?

Based on the data obtained from the Censuses of Population, Households and Dwelling, conducted in 1994 and 2002, in Macedonia it is noted that the share of single households in the total number of households slight increased from 8.9 in 1994 to 9.5 \% in 2002. In terms of gender, women who live alone are dominant, and that ratio (two-thirds of women and one-third of men) has hardly changed in relation to the two census periods (See Table 4). According to age, the most common group of people living alone are the elderly, such as people aged 65 and over.

Table 4: Number and percentage of single person household

\begin{tabular}{|c|c|c|c|c|}
\hline \multirow{2}{*}{ Sex } & \multicolumn{4}{|c|}{ Year } \\
\cline { 2 - 5 } & \multicolumn{2}{|c|}{1994} & \multicolumn{2}{c|}{$\mathbf{2 0 0 2}$} \\
\cline { 2 - 5 } & $\%$ & Number & $\%$ & Number \\
\hline Male & 36,46 & 16.273 & 36,40 & 19.605 \\
\hline Female & 63,54 & 28.364 & 63,60 & 34.256 \\
\hline Total & 100,00 & 44.637 & 100,00 & 53.861 \\
\hline
\end{tabular}

Source: Same as Table 3

Such a structure of households shows that living alone in Macedonia is not a matter of choice, but the result of many circumstances: the death of a partner, divorce and the inability to find a partner. In that respect, the question remains, why is the low participation of young people in single-family households? Is it because young people respect the traditional way of life or the predominance of reasons to look for it in the low economic power of the population in order to influence the expansion of the range of residential choice?

\section{Concluding remarks}

The presented data indicate that the Macedonian approach to the European context is approaching, in the context of the number and structure of families and households. In the Macedonian context, nuclear-type families predominate, namely families with a married couple with children. The size of the families is decreasing, and the population living in a family institution is de- 
creasing, and the participation of persons living in a one-member household is increasing. It seems that the form of a complete family is without any major changes. In the form of single-parent families, mothers living with their children are in a greater number than fathers.

The expectation is that the family as an institution will be subject to change during the period ahead. The changes will be seen in the growing individualization of lifestyles. It is possible to increase the number of single households, including the younger population, if the standard of living is increased.

Additionally, cohabitation union may be on the rise, as well as the presence of some other form of cohabitation. Due to the ever-increasing phenolmenon of population aging, aging households will be on the rise, especially in rural areas. Given that fertility rates do not show an upward trend, it is unequivocal that the average size of both households will decrease. Of course, in order to get a complete demographic picture of the family, it is necessary to consider the composition of families according to other characteristics, such as education level, type of activity, occupation of men and women, ethnicity, and other selected traits.

\section{References:}

CALDWELl, J. C. AND T. SCHINDLMAYR., 2003. "Explanations of the fertility crisis in modern societies: A search for commonalities." Population Studies. 57, p. 241-63.

FREJKA, T., 2008. "Determinants of Family Formation and Childbearing during the Societal Transition in Central and Eastern Europe." Demographic Research. 19, p. 139-170.

HANTRAIS, L., PhiliPOV, D. AND Billari, C.F., 2006. Policy implications of changing family formation, Population studies, No. 49, Council of Europe Publishing.

HOBCRAFT, J. AND KIERNAN, K., 199.) "Becoming a parent in Europe". Welfare State Programme Discussion Papers (WSP 116). Centre for Analysis of Social Exclusion, The London School of Economics and Political Science, London, UK

HOBCRAFT, J. 1996. Fertility in England and Wales: A Fifty-Year Perspective, Population Studies 50(3), p. 485-524

Kalmijn, M., 2007. “Explaining Cross-National Differences in Marriage, Cohabitation, and Divorce in Europe, 1990-2000." Population Studies. 61, p 24363.

Montoro-Gurich, C., GARCiA-Vivar, C., 2019. The family in Europe: Structure, intergenerational solidarity, and new challenges to family health. Journal of Family Nursery 2019, 25, 1-20. 